\title{
Effects of short-duration grazing on winter annuals in the Texas Rolling Plains
}

\author{
JEFFREY R. WEIGEL, GUY R. MCPHERSON, AND CARLTON M. BRITTON
}

\section{Abstract}

A study was conducted in the Texas Rolling Plains to test the hypotheses that short-duration grazing increases plant density and diversity in grasslands. Densities of 9 species of winter annual forbs and 2 species of annual grass were compared in short-duration grazed and ungrazed areas for 2 years. Livestock grazing in spring and early summer affected density of 8 winter annuals the following winter. Densities of 2 grasses [little barley (Hordeum pusillum Nutt.) and six-weeks fescue (Vulpia octoflora [Walt.] Rydb.)] and 3 forbs [common broomweed (Xanthocephalum dracunculoides [DC.]), Gordon's bladderpod (Lesquerella Gordonii [Gray] Wats.), and Texas filaree (Erodium texanum Gray.)] were higher in grazed areas; 3 forbs [bitterweed (Hymenoxys odorata DC.), spurge (Euphorbia sp.), and woolly plaintain (Plantago patagonica Jacq.) were more abundant in exclosures. Richness and diversity of winter annuals generally were not affected by grazing. Increased precipitation during germination and establishment greatly increased the density of winter annuals.

Key Words: plant density, plant diversity, soil strength

Short-duration grazing (SDG) is an intensive, rotational grazing system which uses relatively short grazing periods separated by long rest periods, and high stocking densities to manipulate grazing pressure, forage utilization, and subsequent forage and livestock production (Ralphs et al. 1984). Proponents of SDG have suggested that it closely approximates grazing patterns of native herbivores (Savory and Parsons 1980, Savory 1983, Walter 1984). These authors suggest that dense concentrations of animals provide a beneficial animal impact on soil called 'herd effect'. Herd effect purportedly improves grassland condition by 'chipping' the soil surface, thereby enhancing infiltration (Blackburn 1984, Thurow et al. 1986), herbage production, and seedling emergence.

The objective of this study was to document density of winter annual forb and grass species following SDG during the flowering and seeding period. Density in ungrazed exclosures was also recorded to test the hypotheses that SDG increases density of individual species and SDG increases diversity of annuals in a grassland community.

\section{Materials and Methods}

Research was conducted in 1985 and 1986 at the Texas Tech Experimental Ranch $10 \mathrm{~km}$ southeast of Justiceburg (Garza County), Texas $\left(101^{\circ} 11^{\prime} \mathrm{W}, 32^{\circ} 58^{\prime} \mathrm{N}\right)$. Study plots were located in a honey mesquite/tobosagrass/alkali sacaton (Prosopis glandulosa var. glandulosa Torr./ Hilaria mutica [Buckl.] Benth./Sporobolus airoides [Torr.] Torr.) grassland in the Texas Rolling Plains (Gould 1969; nomenclature follows Correll and Johnston 1970). Regional climate is semiarid, with two-thirds of the $490 \mathrm{~mm}$ of

\footnotetext{
At the time of research, authors were research assistant, research assistant, and professor, Department of Range and Wildlife Management, Texas Tech University, Lubbock 79409. Current address of J.R. Weigel is The Nature Conservancy, P.O. Box 1440, San Antonio, Texas 78295; and the current address of G.R. McPherson is Range Science Department, Texas A\&M University, College Station, Texas 77843. This study is a contribution of the College of Agricultural Sciences, Texas Tech University, No. T-9-503. Authors wish to thank Mary and M. Robert Candee, Perry Grissom, Sheila Merrigan, John Pitts, Allen Rasmussen, and Gretchen Scott for technical assistance. David B. Wester provided helpful suggestions on the manuscript.

Manuscript accepted 13 December 1988
}

average annual precipitation falling from May to October. Longterm average precipitation during the fall-winter (September-February) period of peak emergence of annual species is $170 \mathrm{~mm}$ (NOAA 1985). Study site soils were nearly level Stamford clays (fine, montmorillonitic, thermic Typic Chromusterts) intermixed with small areas of Vernon clay loams (fine, mixed, thermic Typic Ustochrepts). Stamford soils contain predominantly montmorillonitic clays with high shrink-swell potential (Richardson et al. 1965).

The site was continuously grazed at a moderate intensity by cattle before 1984. It was burned in February 1983 and sprayed with triclopyr (((3,5,6-trichloro-2-pryridinyl)oxy)acetic acid) at a rate of $0.5 \mathrm{~kg}$ a.e. $/$ ha in July 1983 for control of honey mesquite. At the time of herbicide application, annual and perennial forbs were dormant and thus not affected by treatment. A six-pasture SDG system was established in 1984. Since 1984, pastures have been grazed by livestock seasonally from mid-April to mid-July each year. Fire, herbicide application, and grazing had minimal influence on perennial plant composition. Pastures were characterized by relatively homogeneous stands of tobosagrass and alkali sacaton, under short $(1-1.5 \mathrm{~m})$ mesquite plants. Animals were sequentially rotated from pasture to pasture during the grazing season; adjustments in length of grazing and rest periods were based on forage growth and availability (Savory and Parsons 1980, Savory 1983).

Study plots were located in a representative, 14-ha pasture in the six-pasture system. Plots were located in a 2-ha area about $550 \mathrm{~m}$ from the single watering point of the $800-\mathrm{m}$ long triangular pasture. The study pasture was grazed by 60 (1985) and 42 (1986) yearling Hereford/Angus crossbred steers for 3 periods each year. Stocking rates were twice (1985) and 1.5 times (1986) those recommended (SCS staff, pers. comm.) for moderate, yearlongcontinuous grazing. In both years, the initial 2 grazing periods were 7 days, followed by rest periods of 35 and 21 days in 1985 and 33 and 30 days in 1986. A final grazing period of 3 days in 1985 and 2 days in 1986 occurred before removal of all animals.

A randomized complete block design with 8 blocks was used. Thirty-two, 0.01- $\mathrm{m}^{2}$ plots were permanently marked in each block, half in randomly located ungrazed wire-mesh exclosures. A small quadrat size was selected because winter annuals were small and numerous (Kershaw and Looney 1985). Each of 4 exclosures per block contained 4 ungrazed plots; 4 groups of 4 grazed plots were located nearby. Grazed plots were located at least $3 \mathrm{~m}$ from exclosures and were marked belowground to avoid increased trampling by animals attracted to exclosure fences or aboveground plot markers. A metal detector was used to locate plots on sampling dates (Weigel and Britton 1986). Blocks were relocated and new plots established before the second grazing season; plots were located in the same 2-ha area each year.

Herbaceous foliar cover of perennial plants was estimated photographically in grazed areas and exclosures after each grazing season. Black-and-white photographs were taken with a 35-mm camera and $50-\mathrm{mm}$ lens from $1.5 \mathrm{~m}$ above $16,0.25-\mathrm{m}^{2}$ plots in each treatment in each block $(\mathrm{N}=128 /$ treatment). A dot-grid overlay ( 50 
dots / grid) was used to measure foliar cover of individual plots.

Soil strength was determined with a proving-ring penetrometer (Soiltest CN-970) after each grazing season. Soil strength is highly correlated with soil bulk density, a measure of soil compaction (Gifford et al. 1977). Eighty measurements per treatment per block were taken in groups of 20 closely spaced $\left(0.5-\mathrm{m}^{2}\right.$ area) samples ( $N=640$ measurements per treatment).

Beginning with the first post-grazing seedling emergence event in October 1985, density of all annual species was recorded bimonthly through February 1987, when the onset of a third season of grazing forced termination. Sampling was not conducted during summer when the previous season's plants had senesced and the next season's plants had not yet germinated. Sample dates were classified as either Season 1 (1985-86) or Season 2 (1986-87) based on phenology of species studied. Four and 3 sample dates comprised Seasons 1 and 2, respectively.

Species recorded in at least $5 \%$ of plots for any date-treatment combination were analyzed for treatment response (Gauch 1982) using analysis of variance with 8 blocks and 2 treatments. In addition, mean species richness (number of species per quadrat), and mean diversity were estimated for each date and treatment using all species. Diversity was estimated with Simpson's c (which decreases with increasing heterogeneity) and Shannon's $H$ (which increases with increasing heterogeneity) (Greig-Smith 1983). Diversity indices were highly correlated (grazed $r=-0.99$, ungrazed $r=-0.96$ ); only $\mathrm{H}$ is presented.

\section{Results}

Nine species of winter annual forbs and 2 species of annual grass were analyzed (Table 1). Seven additional species of annual forbs

Table 1. Scientific and common names of common annual forbs and grasses in the Texas Rolling Plains, 1985-1987.

\begin{tabular}{ll}
\hline \hline Scientific Name & Common Name \\
\hline Forbs: & rabbit tobacco \\
Evax verna Raf. & common broomweed \\
Xanthocephalum dracunculoides (DC.) & \\
Shinners. & woolly plantain \\
Plantago patagonica Jacq. & red-seeded plantain \\
Plantago rhodosperma Dcne. & spurge \\
Euphorbia sp. & bitterweed \\
Hymenoxys odorata DC. & astragalus \\
Astragalus sp. & Gordon's bladderpod \\
Lesquerella Gordonii (Gray) Wats. & Texas filaree \\
Erodium texanum Gray. & \\
Grasses: & little barley \\
Hordeum pusillum Nutt. & six-weeks fescue \\
Vulpia octoblora Walt.) Rydb. &
\end{tabular}

'Nomenclature follows Correll and Johnston 1970.

were encountered but not analyzed because of low frequencies $(<5 \%)$ for each date-treatment combination. Since date $X$ treatment interactions were significant $(P<0.05)$ the response of annuals to grazing was compared within dates.

SDG influenced density of both annual grasses and 6 of 9 forbs during at least 1 sampling date (Fig. 1). Density differences between grazed and ungrazed plots were most prevalent during Season 1, when densities of all species were relatively high. Season 2 was characterized by lower densities and little treatment response. Densities of rabbit's tobacco (Evax verna Raf.), red-seeded plantain (Plantago rhodosperma Dene.), and astragalus (Astragalus sp.) did not differ $(P>0.10)$ in any period (Fig. 1a). Decreased $(P<0.05)$ herbaceous cover and increased soil strength was associated with grazed areas (Table 2).

Mean richness varied from 2.1 to 4.1 species/quadrat, and did
Table 2. Mean ( \pm S.E.) herbaceous foliar cover and soil strength in grazed areas and exclosures following short-duration grazing in the Texas Rolling Plains.

\begin{tabular}{lccccc}
\hline \hline & \multicolumn{2}{c}{ Foliar cover } & & \multicolumn{2}{c}{ Soil strength } \\
\cline { 2 - 3 } \cline { 5 - 6 } Season & Grazed & Ungrazed & & Grazed & Ungrazed \\
\hline 1 & & & & & \\
1 & $14 \pm 1$ & $18 \pm 1$ & & $0.92 \pm 0.01$ & $0.67 \pm 0.01$ \\
2 & $20 \pm 1$ & $29 \pm 2$ & & $1.13 \pm 0.01$ & $0.85 \pm 0.01$ \\
\hline
\end{tabular}

not differ between treatments on any date. Mean diversity was higher $(P<0.05)$ in ungrazed quadrats $(H=0.87)$ than grazed quadrats $(H=0.81)$ on 4 February 1986; diversity did not differ $(P>0.10)$ between treatments on other dates. Shannon-Weaver's $H$ varied from 0.52 to 1.00 .

\section{Discussion}

Above-normal fall precipitation in both seaons provided excellent germination conditions both years. However, densities of most forbs and both grasses were higher in Season 1 regardless of treatment. Lower density of these species in Season 2 may have been related to very low Season 1 winter precipitation and very high Season 2 fall precipitation. Beatley (1974) attributed late winter mortality of Mojave Desert annuals to decreased soil moisture during the critical winter growth period, although some mortality occurred even in years with adequate moisture. Several researchers have demonstrated density-dependent thinning in desert annuals (Fowler 1986). Season 2 fall precipitation occurred early in that period, and was nearly twice normal (Fig. 2). This stimulated vigorous growth of perennial grass dominants, which may have reduced germination and survival of annuals through preemption of soil moisture (Friedman et al. 1977). Thus, belowaverage precipitation during previous year's flowering and aboveaverage precipitation prior to germination may have reduced current year's densities.

Density differences between years probably resulted from differential precipitation patterns, and not from fire-herbicide treatments. Winter annual densities in this area recover to pretreatment levels within 2 years (Steuter and Wright 1983). Precipitation had a greater impact on densities of winter annual than grazing, which is consistent with other studies (Beatley 1974, Fowler 1986). Despite the overriding influence of precipitation which tended to mask treatment effects, the structure of the winter annual community was effected by SDG.

Little is known about life history characteristics of any of the species studied. The lack of autecological information makes explanation of species' responses highly speculative. Winter annuals usually are regarded as stress-tolerant ruderals capable of exploiting bare and/or trampled areas (Grime 1979). Mechanisms by which plants establish in these areas have been reviewed by Peart (1984) and Booth (1987) in the context of seed morphology and by Evans and Young (1987) in the context of seedbed microenvironment. Five species [little barley, six-weeks fescue (Fig. 1b), common broomweed, Gordon's bladderpod, Texas filaree (Fig. 1c)] exhibited this ability at some time during this study. Decreased herbaceous cover and increased soil strength in grazed areas created favorable microsites for establishment of these species. However, 6 species (all forbs) displayed no response [rabbit's tobacco, astragalus, red-seeded plantain (Fig. la)] or had higher densities in quadrats excluded from grazing [spurge, bitterweed, woolly plantain (Fig. 1d)]. These species were not favored by disturbance in the form of SDG, at least in the short term.

Compared to no grazing, the primary effects of SDG are to 

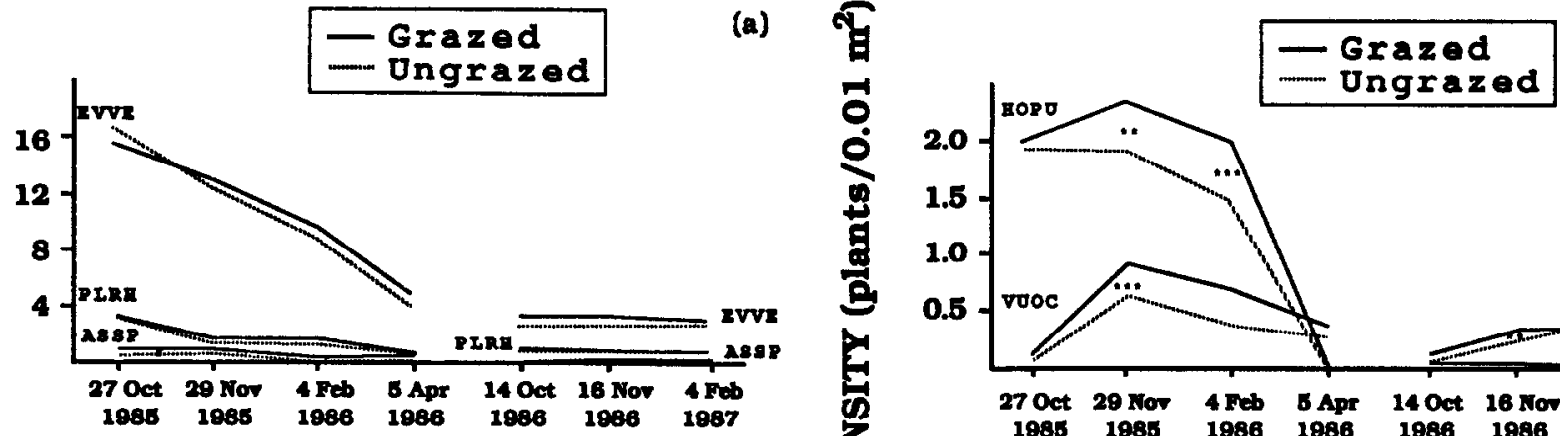

DATE

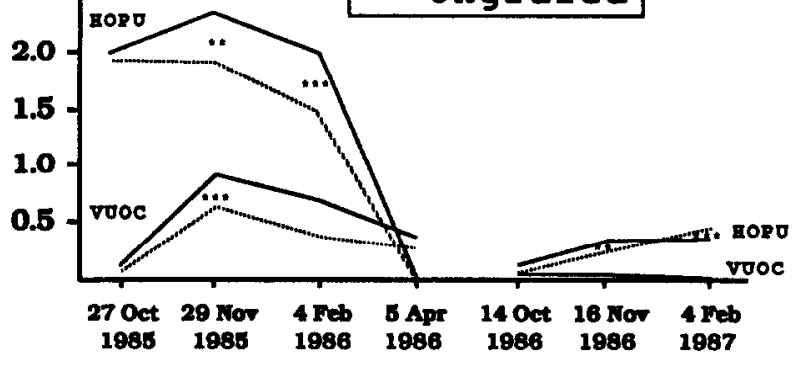

DATE
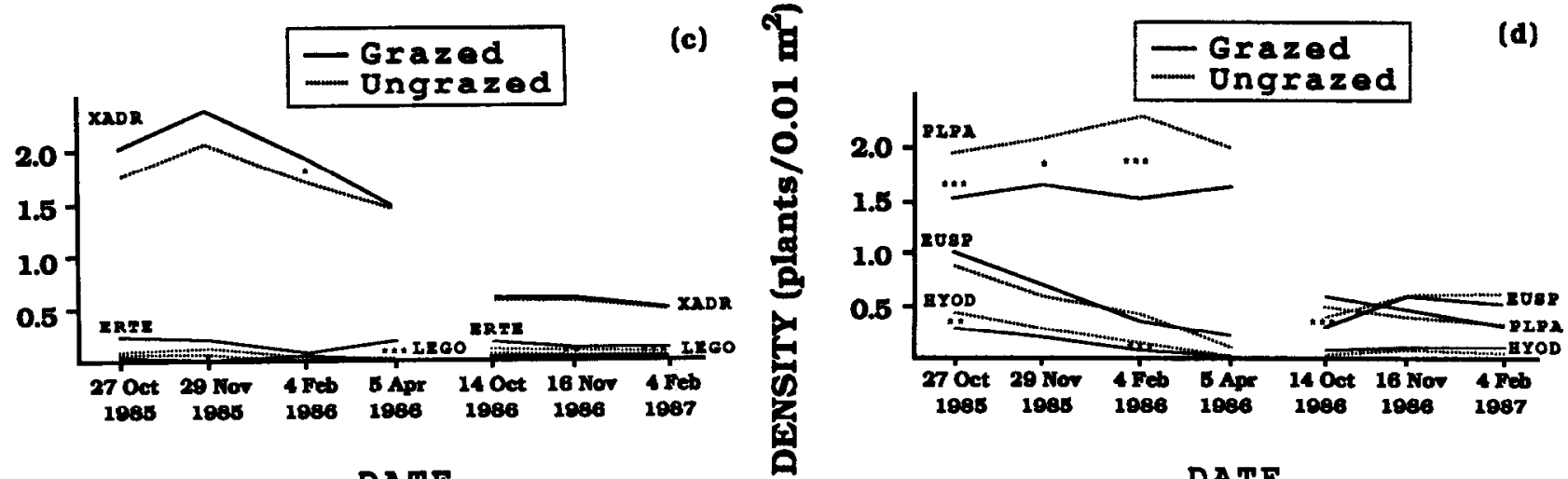

DATE

DATE

Fig. 1. Density of winter annuals following short-duration grazing in spring and summer in western Texas. Differences in density between grazed and ungrazed plots are noted by $*(\mathrm{P}<0.10), *(\mathrm{P}<0.05)$, or ${ }^{* * *}(\mathrm{P}<0.01)$. (a) Forb species with similar densities in grazed and ungrazed quadrats: Evax verna (EVVE), Plantago rhodosperma (PLRH), Astragalus sp. (ASSP). (b) Grasses: Hordeum pusillum (HOPU), Vulpia octoflora (VUOC). (c) Forb species with higher densities in grazed areas on at least one sampling date: Xanthocephalum dracunculoides (XADR), Erodium texanum (ERTE), Lesquerella Gordonii (LEGO). (d) Forb species with higher densities in exclosures on at least one sampling date: Plantago patagonica (PLPA), Euphorbia sp. (EUSP), Hymenoxys odorta (HYOD).

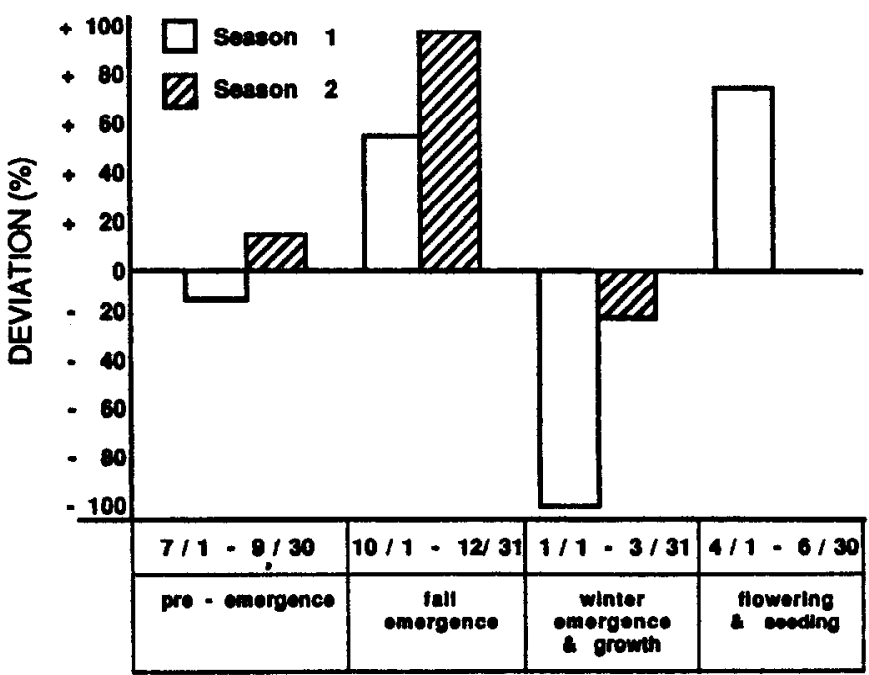

Fig. 2. Deviations from long-term average precipitation by phenological stage of winter annuals. remove vegetation cover and alter soil microtopography. A smooth soil surface devoid of plant cover represents the harshest microenvironment for seedling establishment (Evans and Young 1987). Young et al. (1975) listed 3 adaptations of colonizing species to bare, smooth seedbeds which predominate on grazed sites: (1) rapid germination (e.g., common broomweed); (2) self-burial of seeds (e.g., Texas filaree); and (3) mucilaginous seed coats (e.g., Plantago spp.). The response of common broomweed to SDG is consistent with these hypotheses and with the results of other studies on the species (Gordon 1982, Steuter and Wright 1983). Texas filaree density was higher in grazed than ungrazed quadrats, which is also consistent with the hypotheses of Young et al. (1975). However, red-seeded plantain density did not differ between treatments, and woolly plantain density was higher in ungrazed than grazed quadrats. The response of Plantago spp. and other winter annuals which did not increase under SDG is not readily explainable by observed grazing-induced changes in light penetration or microtopography. The latter may have been masked by extensive cracking of the Vertisol soils throughout the study site.

Differential seed predation and seedling herbivory by insects and small mammals between grazed and ungrazed areas can contribute significantly to composition of desert annual communities 
(Inouye et al. 1980). Different insect communities in exclosures may have resulted from greater aboveground biomass and stratification of herbaceous vegetation. However, seed and vegetation preferences of insects and small mammals have not been reported for the plant species studied. Differential herbivory between species is presented as a potential but untested mechanism affecting community structure.

Competition with perennial plants (especially for light or space) and other winter annuals may have affected density of some species. Mean basal cover of dominant perennials was $8.6 \%$ in the study area and was evenly divided between tobosagrass and alkali sacaton in grazed and ungrazed plots (Weigel 1987). Temporal and spatial variability in competitive intensity between species can be quite high (Fowler 1986), and grazing can alter competitive relationships between species (McNaughton 1985, Belsky 1986). Furthermore, germination of winter annuals may be densitydependent, decreasing with increased seedling density (Inouye 1980). For example, invasion of "safe sites" (Harper 1977) in grazed areas by species which germinate early in a season (e.g., Texas filaree, common broomweed) may inhibit subsequent germination, thereby reducing density of late-germinating species. The issues of density-dependent germination and mortality are beyond the scope of the current study.

SDG is capable of altering community structure of winter annuals in the near-term ( 3 to 9 months after grazing). Directional change to favor some species at the expense of others presumably would continue over time as the latter species became continuously less abundant. The magnitude of the shift in community structure cannot be adequately assessed with a short-term study; further studies addressing the impacts on annual species over longer periods of SDG are needed. Furthermore, basic autecological data (e.g., germination requirements) are needed for most winter annuals encountered in this study.

\section{Literature Cited}

Beatley, J.C. 1974. Phenological events and their environmental triggers in Mojave Desert ecosystems. Ecology 55:856-863.

Belaky, A.J. 1986. Does herbivory benefit plants? A review of the evidence. Amer. Natur. 127:870-892.

Blackburn, W.H. 1984. Impacts of grazing intensity and specialized grazing systems on watershed characteristics and responses, p. 927-983. In: Developing strategies for rangeland management. Nat. Res. Counc./Nat. Acad. Sci., Westview Press, Boulder, Colo.

Booth, D.T. 1987. Diaspores of rangeland plants, ecology and management. p. 202-211 In: G.W. Frasier and R.A. Evans (eds.) Seed and seedbed ecology of rangeland plants. USDA/ARS, Tucson, Ariz.

Correll, D.S., and M.C. Johnston. 1970. Manual of the vascular plants of Texas. Texas Res. Found., Renner, Texas.
Evans, R.A., and J.A. Young. 1987. Seedbed microenvironment, seedling recruitment, and plant establishment on rangelands. p. $212-220 \mathrm{In}: \mathrm{G}$.W. Frasier and R.A. Evans (eds.) Seed and seedbed ecology of rangeland plants. USDA/ARS, Tucson, Ariz.

Fowler, N.F. 1986. The role of competition in plant communities in arid and semiarid regions. Annu. Rev. Ecol. and Sys. 17:89-110.

Friedman, J., G. Orshan, and Y. Ziger-Crir. 1977. Suppresion of annuals by Artemisia herba-alba in the Negev Desert of Israel. J. Ecol. 65:413-426.

Gauch, H.G. 1982. Multivariate analysis in community ecology. Cambridge Univ. Press, Cambridge.

Gifford, G.F., R.M. Faust, and G.B. Coltharp. 1977. Measuring soil compaction on rangeland. J. Range Manage. 30:457-460.

Gould, F.W. 1969. Texas plants: a checklist and ecological summary. Texas Agr. Exp. Sta. Rep. MP-585.

Gordon, R.A. 1982. The ecology and control of common broomweed. Ph.D. Diss., Texas Tech Univ., Lubbock, Tex.

Grieg-Smith, P. 1983. Quantitative plant ecology. Third edition. Univ. California Press, Berkeley.

Grime, J.P. 1979. Plant strategies and vegetation processes. John Wiley Publ. Co. Inc. New York.

Harper, J.L. 1977. Population biology of plants. Academic Press, London.

Inouye, R.S. 1980. Density-dependent germination response by seeds of desert annuals. Oecologia 46:235-238.

Inouye, R.S., G.S. Byers, and J.H. Brown. 1980. Effects of predation and competition on survivorship, fecundity, and community structure of desert annuals. Ecology 61:1344-1351.

Kershaw, K.A., and J.H.H. Looney. 1985. Quantitative and dynamic plant ecology. Third edition. Edward Arnold Publ. Ltd., London.

MeNaughton, S.J. 1985. Ecology of a grazing ecosystem: the Serengeti. Ecol. Monog. 55:259-294.

National Oceanic and Atmospheric Administration. 1985. Climatological data annual summary-Texas 1984 . Vol. 89, No. 13. Asheville, N.C.

Peart, M.H. 1984. The effects of morphology, orientation and position of grass diaspores on seedling survival. J. Ecol. 72:437-453.

Ralphs, M.H., M.M. Kothmann, and L.B. Merrill. 1984. Proper stocking for short duration grazing. Texas Agr. Exp. Sta. Rep. PR-4190.

Richardson, W.E., D.G. Grice, and L.A. Putnam. 1965. Soil survey of Garza County, Texas. USDA Soil Conserv. Serv.

Savory, A. 1983. The Savory grazing method or holistic resource management. Rangelands 5:155-159.

Savory, A., and S. Parson. 1980. The Savory grazing method. Rangelands 2:234-237.

Steuter, A.A., and H.A. Wright. 1983. Spring burning effects on redberrymixed grass habitats. J. Range Manage. 36:161-164.

Thurow, T.L., W.H. Blackburn, and C.A. Taylor. 1986. Hydrologic characteristics of vegetation types as affected by livestock grazing systems, Edwards Plateau, Texas. J. Range Manage. 39:505-509.

Walter, J. 1984. Rangeland revolutionary: an interview with Allen Savory. J. Soil and Water Conserv. 39:235-240.

Weigel, J.R. 1987. Effects of short-duration grazing trampling on seedling emergence and soil strength. M.S. Thesis, Texas Tech Univ., Lubbock, Tex.

Weigel, J.R., and C.M. Britton. 1986. Use of a metal detector to locate permanent plots. J. Range Manage. 39:565.

Young, J.A., R.A. Evans, and B.L. Kay. 1975. Dispersal and germination dynamics of broadleaf filaree, Erodium botrys (Cav.) Bertol. Agron. J. 67:54-57. 